CZASOPISMO INŻYNIERII LĄDOWEJ, ŚRODOWISKA I ARCHITEKTURY JOURNAL OF CIVIL ENGINEERING, ENVIRONMENT AND ARCHITECTURE

JCEEA, t. XXXIII, z. 63 (4/16), październik-grudzień 2016, s. 419-432

\author{
Adam Pawel PIECH \\ Anna BASZAK ${ }^{2}$
}

\title{
PIERWIASTKI ŚLADOWE W WYBRANYCH WODACH MINERALNYCH DOSTECPNYCH W HANDLU
}

\begin{abstract}
Butelkowane wody mineralne stanowią istotne źródło zaspokajania zapotrzebowania na wodę w codziennej diecie człowieka. Ze względu na łatwość przyswajania przez organizm składników mineralnych zawartych w wodach mineralnych konieczne jest świadome wybieranie produktu o składzie dostosowanym do indywidualnych potrzeb. Oprócz makroskładników, których charakterystyka ilościowa zawsze widnieje na etykietach, wody mineralne zawierają również mikroelementy. Celem pracy była analiza koncentracji pierwiastków śladowych w 22 butelkowanych wodach mineralnych dostępnych w handlu na terenie Rzeszowa. Artykuł zawiera główne zagadnienia dotyczące znaczenia wody dla prawidłowego funkcjonowania organizmu oraz wpływu mikroelementów na zdrowie człowieka. W badaniach zastosowano metodę całkowitego odbicia promieniowania rentgenowskiego TXRF. Analizy wykazały obecność 18 pierwiastków śladowych w badanych wodach: Al, As, Ba, Br, Co, Cr, Cu, Fe, Ge, I, Mn, Ni, P, Rb, Se, Sr, Ti, Zn. Najwyższe stężenia mikroskładników w przeważającej większości występują w wodach leczniczych. Żadna z badanych wód mogąca służyć jako stałe źródło płynów w diecie (wody nisko-, średnio- i wysokozmineralizowane) nie zawiera mikroskładników w ilości, która pozwalałaby na fizjologiczno-odżywcze oddziaływanie na organizm. Dodatkowo wykazano, że pomiędzy stężeniem bromu i germanu istnieje silna korelacja dodatnia $\left(R^{2}=0,993\right)$.
\end{abstract}

Słowa kluczowe: mikroelementy, woda mineralna, wody butelkowane, german

\section{Wstęp}

Woda jest niezbędna do prawidłowego funkcjonowania ciała ludzkiego. Jej funkcje nie polegają tylko na nawadnianiu organizmu, ale również na dostarczeniu niezbędnych pierwiastków jak na przykład magnezu, wapnia czy sodu.

\footnotetext{
${ }^{1}$ Autor do korespondencji / corresponding author: Adam Paweł Piech, Politechnika Rzeszowska, Zakład Oczyszczania i Ochrony Wód, al. Powstańców Warszawy 6, 35-959 Rzeszów, tel. 178651949, apiech@prz.edu.pl

2 Anna Baszak, Politechnika Rzeszowska
} 
Dziedziną nauki, zajmującą się wykorzystaniem wody i innych surowców naturalnych w celach leczniczych jest balneologia, krenoterapia zaś jest kuracją pitną. Jest to jedna $z$ najczęściej wykorzystywanych metod lecznictwa uzdrowiskowego [7].Jednak dzięki intensywnemu rozwojowi przemysłu rozlewniczego wykorzystywanie korzystnych właściwości wód i rozpuszczonych w nich składników mineralnych wykroczyło poza granicę uzdrowisk. Nieograniczony wręcz dostęp do butelkowanych wód mineralnych wymaga od konsumentów racjonalnego wyboru takiej wody, która będzie dostosowana do ich indywidualnych potrzeb.

Na właściwości zdrowotne wód mineralnych mają wpływ nie tylko składniki główne, o stężeniu których producent jest zobowiązany poinformować na etykiecie, ale również mikroskładniki [5]. Istotne zatem jest poznanie zawartości tych pierwiastków, zarówno pod względem jakościowym jak i ilościowym.

Pojęcie wody mineralnej po raz pierwszy zostało formalnie sprecyzowane na Międzynarodowym Kongresie Balneologicznym w Neuheim w 1911 roku. Odnosiło się ono do wód, które w jednym litrze zawierają powyżej $1000 \mathrm{mg}$ rozpuszczonych składników mineralnych [4]. Obecnie podział i definicje wód mineralnych regulowane są w europejskich i krajowych aktach prawnych.

Woda stanowi środowisko dla przebiegu wielu reakcji biochemicznych, jest głównym składnikiem ciała ludzkiego. W zależności od wieku, płci i budowy ciała jej udział w ogólnej masie ciała waha się w granicach od $45 \%$ u ludzi starszych, do nawet $80 \%$ u noworodka [3]. Ciało ludzkie nie ma jednak możliwości magazynowania wody, więc w celu zachowania prawidłowego funkcjonowania organizmu musi być ona stałym punktem codziennej diety. Zapotrzebowanie na wodę również różni się w zależności od wieku, płci, masy ciała, przeciętnie wynosi ono $2 \mathrm{dm}^{3}$ na dobę. Można założyć więc, że dla człowieka żyjącego 70 lat, ilość wody spożywanej przez całe życie kształtuje się na poziomie 50 tys $\mathrm{dm}^{3}$. Oznacza to, że ciągłe spożywanie wody zawierającej nawet minimalne ilości szkodliwych substancji może prowadzić do skumulowania ich w organizmie [6]. Jednocześnie picie wody o bardzo niskiej mineralizacji lub wody zdemineralizowanej, otrzymanej na przykład w wyniku zastosowania filtrów RO (odwróconej osmozy), może być przyczyną zaburzonej równowagi elektrolitycznej [2].

Wpływ spożywania wód mineralnych na zdrowie człowieka nie jest uzależniony tylko od zawartości głównych składników, ale również od stężenia mikroelementów. Zbyt duża lub zbyt mała zawartość określonych pierwiastków może oddziaływać na organizm człowieka. Woda w prawdzie dostarcza zaledwie $10 \%$ dziennego zapotrzebowania na składniki mineralne, są jednak one znacznie łatwiej przyswajalne niż składniki mineralne dostarczane z pożywieniem. Mikroskładniki w żywności występują zwykle w formie trudno rozpuszczalnych i źle przyswajalnych związków kompleksowych. Ponadto intensyfikacja rolnictwa i hodowli oraz procesy przetwarzania żywności są przyczyną zmniejszania się zawartości potrzebnych pierwiastków w przyjmowanym pokarmie $[2,5]$. 
Znane są pierwiastki, które ograniczają lub uniemożliwiają przyswajanie innych mikroskładników przez organizm. Jednak odpowiednie proporcje poszczególnych pierwiastków przyjmowanych z pokarmem i wodą nie są w pełni poznane. Istotne zatem jest spożywanie wód mineralnych i wód leczniczych, w których występują różnorodne mikroskładniki w korzystnych, łatwo przyswajalnych formach.

Właściwości lecznicze wód podziemnych związane są z obecnością gazów (wody siarczkowe, szczawy) lub występowaniem charakterystycznych właściwości fizycznych (wody radonowe, termalne). Istotną grupę stanowią wody swoiste, czyli takie, których właściwości wynikają z odpowiednio wysokiego stężenia - głównie na poziomie $\mathrm{mg} \cdot \mathrm{dm}^{-3}$ - składników podrzędnych lub mikroskładników. Do pierwiastków tych mogą być zaliczane fluor, jod, arsen, brom, bor, bar, lit, stront. Dodatkowo istnieją mikroskładniki, które wodom podziemnym nadają korzystny lub nawet leczniczy wpływ już przy zawartości rzędu $\mu g \cdot d m^{-3}$. Są to m.in. mangan, wanad, kobalt, cynk, selen, chrom, miedź i molibden. Pierwiastki te nazywane są biokatalizatorami. Pełnią istotną funkcję w organizmie, ponieważ budują niektóre enzymy oraz usprawniają przemiany biochemiczne. Możliwe jest, że wraz z postępem nauki, przede wszystkim medycyny i balneologii poznane będą funkcje w organizmie innych, niewymienionych powyżej mikroskładników [5].

Celem pracy było badanie zawartości pierwiastków śladowych w wybranych butelkowanych wodach mineralnych dostępnych w handlu oraz porównanie tych wód pod względem występowania mikroskładników.

\section{Metodologia wykonania badań}

\subsection{Charakterystyka urządzenia analitycznego}

Podstawowym instrumentem wykorzystanym w trakcie badań był spektrometr S2 PICOFOX. Urządzenie to charakteryzuje się możliwością szybkiego i sprawnego wykonywania analiz ilościowych oraz mikroanaliz próbek stałych i ciekłych oraz zanieczyszczeń na filtrach. Metoda wykorzystywana w tym spektrometrze to fluorescencyjna spektrometria rentgenowska całkowitego odbicia TXRF. Granica wykrywalności to $\operatorname{ppm}\left(m g \cdot d m^{-3}\right)$ i ppb $\left(\mu g \cdot d m^{-3}\right)$ [9].

\subsection{Aparatura i odczynniki}

Podczas badań wykorzystano następujące odczyniki:

- aceton $\left(\mathrm{CH}_{3} \mathrm{COCH}_{3}\right)$,

- woda dejonizowana,

- stężony $69 \%$ kwas azotowy $\left(\mathrm{HNO}_{3}\right)$,

- $10 \%$ kwas azotowy $\left(\mathrm{HNO}_{3}\right)$,

- kwas solny 1:1, 
- silikon (roztwór w izopropanolu),

- roztwór galu $1000 \mu \mathrm{g} \cdot \mathrm{dm}^{-3}$.

Wykorzystana aparatura:

- suszarka laboratoryjna,

- waga analityczna Radwag Max50/1/WH,

- dygestorium,

- płyta grzewcza,

- wytrząsarka o ruchu drgającym Lab Dancer, IKA,

- piec muflowy,

- spektrometr rentgenowski S2 PICOFOX, Bruker AXS Microanalysis GmbH.

\subsection{Przygotowanie próbek}

1) Przygotowanie roztworu standardu wewnętrznego: do kolby miarowej o pojemności $10 \mathrm{ml}$ dodano $0,1 \mathrm{ml}$ roztworu galu o stężeniu $1000 \mu \mathrm{g} \cdot \mathrm{dm}^{-3}$ i dopełniono do kreski wodą dejonizowaną Roztwór dokładnie wymieszano. Otrzymano roztwór o stężeniu $10 \mathrm{mg} \cdot \mathrm{dm}^{-3}$.

2) Do próbówek Eppendorfa za pomocą pipety automatycznej wprowadzano po $1 \mathrm{ml}$ badanej wody. Dla każdej wody przygotowano po 3 próbki.

3) Do każdej próbki za pomocą pipety automatycznej dodano po $10 \mu \mathrm{l}$ roztworu standardu wewnętrznego. Próbki dokładnie mieszano na wytrząsarce laboratoryjnej o ruchu drgającym.

4) Nośniki (dyski kwarcowe) ułożono na płycie grzejnej. Za pomocą pipety automatycznej o pojemności $6 \mu l$ na centralną część nośników nanoszono próbki wody. Po odparowaniu wody nanoszono olejną warstwę. Proces powtarzano do uzyskania wyraźnej warstwy analitu [1].

Procedura czyszczenia nośników i pomiar kontrolny w celu sprawdzenia czystości wykonano zgodnie z metodyką producenta urządzenia [1].

\section{Charakterystyka badanych wód}

W badaniach wykorzystano 22 wody butelkowane dostępne w handlu na terenie Rzeszowa. W Tabeli 1 przedstawiono ich skład chemiczny, ogólną zawartość składników mineralnych oraz klasyfikację wg informacji podanych na etykietach. 
Pierwiastki śladowe w wybranych wodach mineralnych...

Tabela 1. Klasyfikacja, mineralizacja ogólna oraz zawartość składników mineralnych w badanych wodach butelkowanych $\left[\mathrm{mg} \cdot \mathrm{dm}^{-3}\right]$ (na podstawie informacji zawartych na etykietach)

Table 1. Classification, total mineralization and mineral content in bottled mineral waters $\left[\mathrm{mg} \cdot \mathrm{dm}^{-3}\right]$ (information from the labels)

\begin{tabular}{|c|c|c|c|c|c|c|c|}
\hline \multirow{2}{*}{ Nazwa } & \multirow{2}{*}{ Mineralizacja } & \multicolumn{6}{|c|}{ Kationy } \\
\hline & & $\mathrm{Na}^{+}$ & $\mathrm{Ca}^{2+}$ & $M g^{2+}$ & $K^{+}$ & $L i^{+}$ & $F e^{2+}$ \\
\hline \multicolumn{8}{|c|}{ Wody niskozmineralizowane } \\
\hline Primavera & 248,28 & 1,78 & 48,1 & 6,08 & 0,86 & - & - \\
\hline Dobrowianka & 420 & 2 & 58,12 & 33,42 & - & - & - \\
\hline Evian & 489 & 6,5 & 80 & 26 & 1 & - & - \\
\hline \multicolumn{8}{|c|}{ Wody średniozmineralizowane } \\
\hline Jurajska & 500,33 & 10 & 66,1 & 32,8 & 2,2 & - & - \\
\hline Kinga pieninska & 508,676 & 9,2 & 86,97 & 12,82 & 3,46 & - & - \\
\hline Rzeszowianka & 630 & 5,4 & 101 & 26,2 & 3,4 & - & - \\
\hline Nałęczowianka & 650 & 10 & 114,2 & 20 & 2,5 & - & - \\
\hline Perrier & 708 & 11,8 & 155 & 6,8 & - & - & - \\
\hline Cisiowianka & 742 & 11 & 130,3 & 21,9 & $<5$ & - & - \\
\hline SPellegrino & 998 & 33,3 & 174 & 51,4 & - & - & - \\
\hline Celestynka & 1409 & 256 & 74 & 15 & 7 & - & - \\
\hline \multicolumn{8}{|c|}{ Wody wysokozmineralizowane } \\
\hline Piwniczanka & 1729 & 133 & 180 & 87 & 13 & 0,6 & - \\
\hline Saguaro & 1991,6 & 420 & 94 & 35 & - & - & - \\
\hline Muszynianka & 2104 & 98 & 240 & 120 & 9 & - & - \\
\hline Kryniczanka & 2246,1 & 54,71 & 368,92 & 73,209 & 5,27 & - & - \\
\hline Wysowianka & 2896,3 & 619,9 & 142,5 & 47,9 & & - & - \\
\hline \multicolumn{8}{|c|}{ Wody lecznicze } \\
\hline Słotowinka & 3243,6 & 267,4 & 195,2 & 211,2 & 10,31 & - & 0,11 \\
\hline Henryk & 5225,6 & 1231 & 156,7 & 39 & 33 & 1 & - \\
\hline Franciszek & 14814,3 & 4040 & 176,4 & 19,6 & 80,8 & 2,5 & - \\
\hline Zuber & 25006,3 & 6168 & 77,43 & 363,8 & 288,4 & 18,53 & 0,43 \\
\hline Jan & 669,9 & 15,73 & 115,71 & 17,607 & 1,67 & 0,011 & 0,22 \\
\hline Wielka Pieniawa & 1380 & 67,3 & 218 & 26,4 & 38,8 & - & - \\
\hline
\end{tabular}


Tabela 1 (cd.). Klasyfikacja, mineralizacja ogólna oraz zawartość składników mineralnych w badanych wodach butelkowanych $\left[\mathrm{mg} \cdot \mathrm{dm}^{-3}\right]$ (na podstawie informacji zawartych na etykietach)

Table 1 (cont.). Classification, over mineralization and mineral content in bottled mineral waters $\left[\mathrm{mg} \cdot \mathrm{dm}^{-3}\right]$ (information from the labels)

\begin{tabular}{|c|c|c|c|c|c|c|c|}
\hline \multirow{2}{*}{ Nazwa } & \multirow{2}{*}{ Mineralizacja } & \multicolumn{7}{|c|}{ Aniony } \\
\cline { 3 - 7 } & & $\boldsymbol{C l}^{-}$ & $\boldsymbol{S O}_{\mathbf{4}}^{\mathbf{2}}$ & $\boldsymbol{H C O}_{\mathbf{3}}^{-}$ & $\boldsymbol{F}^{-}$ & $\boldsymbol{J}^{-}$ \\
\hline \multicolumn{7}{|c|}{ Wody niskozmineralizowane } \\
\hline Primavera & 248,28 & 4,2 & 13,78 & 160,11 & 0,12 & - \\
\hline Dobrowianka & 420 & - & - & 276,94 & 0,13 & - \\
\hline Evian & 489 & 6,8 & 12,6 & 360 & - & - \\
\hline \multicolumn{7}{|c|}{ Wody średniozmineralizowane } \\
\hline Jurajska & 500,33 & 7,8 & 40,5 & 329,9 & 0,4 & - \\
\hline Kinga pieninska & 508,676 & 5,32 & 12,6 & 360,01 & 0,06 & - \\
\hline Rzeszowianka & 630 & 13,5 & 37 & 442,4 & - & - \\
\hline Nałęczowianka & 650 & 12,6 & - & 448,1 & 0,3 & - \\
\hline Perrier & 708 & 25 & 46,1 & 445 & - & - \\
\hline Cisiowianka & 742 & $<5$ & $<1$ & 539,1 & $<0,5$ & - \\
\hline SPellegrino & 998 & 52 & 430 & 245 & - & - \\
\hline Celestynka & 1409 & 338 & 24 & 584 & 0,4 & 0,5 \\
\hline \multicolumn{7}{|c|}{ Wody wysokozmineralizowane } \\
\hline Piwniczanka & 1729 & - & 32 & 1260 & 0,22 & - \\
\hline Saguaro & 1991,6 & 212,7 & - & 1141 & - & 0,26 \\
\hline Muszynianka & 2104 & 10 & 27,0 & 1600 & - & - \\
\hline Kryniczanka & 2246,1 & 10,3 & 6,15 & 1721,9 & 0,14 & - \\
\hline Wysowianka & 2896,3 & 319,1 & - & 1665,8 & - & 0,52 \\
\hline Słotowinka & 3243,6 & 15,1 & 3,0 & 2479,3 & 0,11 & - \\
\hline Henryk & 5225,6 & 585 & 11,7 & 2989,9 & 0,5 & 0,9 \\
\hline Franciszek & 14814,3 & 2162,9 & 11,7 & 7853 & - & 2,9 \\
\hline Zuber & 25006,3 & 902,8 & 3,0 & 17161 & 0,097 & 1,13 \\
\hline Jan & 669,9 & 43,7 & 49,24 & 343,1 & 0,206 & - \\
\hline Wielka Pieniawa & 1380 & 3,4 & 30,0 & 970 & 0,43 & \\
\hline
\end{tabular}




\section{Wyniki badań i ich omówienie}

Badania własne wykazały, że $\mathrm{w}$ analizowanych wodach butelkowanych występują następujące mikroskładniki: glin (Al), arsen (As), bar (Ba), brom $(\mathrm{Br})$, kobalt $(\mathrm{Co})$, chrom $(\mathrm{Cr})$, miedź $(\mathrm{Cu})$, żelazo $(\mathrm{Fe})$, german $(\mathrm{Ge})$, jod $(\mathrm{I})$, mangan $(\mathrm{Mn})$, nikiel $(\mathrm{Ni})$, fosfor $(\mathrm{P})$, rubid $(\mathrm{Rb})$, selen $(\mathrm{Se})$, stront $(\mathrm{Sr})$, tytan (Ti) i cynk (Zn).Tabela 2 zawiera zestawienie otrzymanych wyników.

Tabela 2. Zawartość mikroskładników w wybranych butelkowanych wodach mineralnych $\left[\mu g \cdot \mathrm{dm}^{-3}\right]$

Table 2. Trace elements in selected bottled mineral waters $\left[\mu g \cdot d m^{-3}\right]$

\begin{tabular}{|c|c|c|c|c|c|c|c|c|c|c|c|}
\hline & \multicolumn{11}{|c|}{ Woda butelkowana } \\
\hline 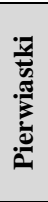 & 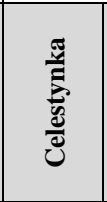 & 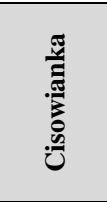 & 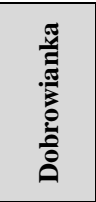 & 言 & 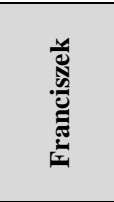 & 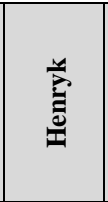 & $\Xi$ & 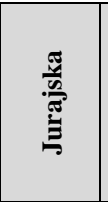 & 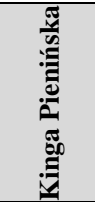 & 丞 & 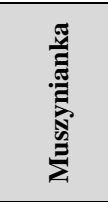 \\
\hline Al. & - & 375,5 & - & - & 8034,67 & 8516,77 & 472,89 & - & - & - & 499,6 \\
\hline As & - & - & 1,42 & - & - & - & - & - & - & - & - \\
\hline $\mathrm{Ba}$ & 2198,08 & 24,65 & 285,99 & 108,96 & 4521,89 & 1756,74 & 214,21 & 77,45 & 134,46 & 989,9 & 1235,53 \\
\hline $\mathrm{Br}$ & - & 23,26 & 17,73 & 12,59 & 12350,8 & 2978,14 & 18,63 & 40,57 & 9,42 & 23,57 & 27,88 \\
\hline Co & - & - & - & - & - & - & 7,12 & - & - & - & - \\
\hline $\mathrm{Cr}$ & - & 1,39 & - & 5,25 & - & - & - & - & 1,61 & 3,72 & - \\
\hline $\mathrm{Cu}$ & - & 1,01 & 1,07 & 0,63 & - & 9,51 & - & 0,81 & 0,81 & 4,36 & 1,91 \\
\hline $\mathrm{Fe}$ & 52,06 & 28,32 & 13,08 & 30,86 & 85,18 & 102,69 & 20,86 & 16,52 & 6,53 & 37,27 & 29,92 \\
\hline $\mathrm{Ge}$ & 1,03 & - & - & - & 53,59 & 17,69 & - & - & - & - & - \\
\hline I & - & - & - & - & 1628,04 & 580,83 & - & - & - & - & - \\
\hline $\mathrm{Mn}$ & - & - & - & 0,8 & 115,17 & 170,14 & 454,27 & - & 0,6 & 132,42 & 342,58 \\
\hline $\mathrm{Ni}$ & - & - & - & - & - & 7,22 & 20,53 & - & - & - & - \\
\hline $\mathrm{P}$ & - & 748,32 & - & - & 3040,60 & 1709,38 & 561,29 & - & - & - & 1242,21 \\
\hline $\mathrm{Rb}$ & 19,01 & 5,08 & 1,385 & - & 386,06 & 125,58 & 2,721 & 5,3325 & 0,5405 & 10,786 & 10,944 \\
\hline $\mathrm{Se}$ & - & - & - & - & - & - & - & - & 0,1625 & - & - \\
\hline $\mathrm{Sr}$ & 1797,24 & 1522,26 & 244,93 & 338,87 & 1814,05 & 705,07 & 514,72 & 1279,34 & 330,37 & 2572,67 & 1652,64 \\
\hline $\mathrm{Ti}$ & - & - & - & - & - & - & - & - & - & - & - \\
\hline $\mathrm{Zn}$ & 10,46 & 5,35 & 74,15 & 3,61 & 64,84 & 41,58 & 8,08 & 5,17 & 6,84 & 6,73 & 11,26 \\
\hline
\end{tabular}


Tabela 2 (cd.). Zawartość mikroskładników w wybranych butelkowanych wodach mineralnych $\left[\mu g \cdot \mathrm{dm}^{-3}\right]$ Table 2 (cont.). Trace elements in selected bottled mineral waters $\left[\mu \mathrm{g} \cdot \mathrm{dm}^{-3}\right]$.

\begin{tabular}{|c|c|c|c|c|c|c|c|c|c|c|c|}
\hline & \multicolumn{11}{|c|}{ Woda butelkowana } \\
\hline 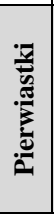 & 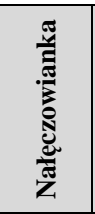 & 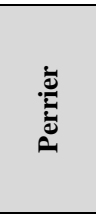 & 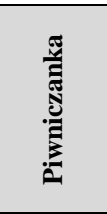 & 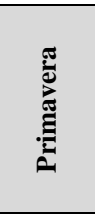 & 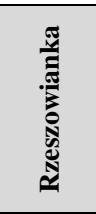 & 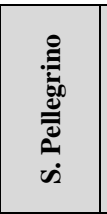 & $\begin{array}{l}\frac{\pi}{E} \\
\text { है } \\
\text { के }\end{array}$ & 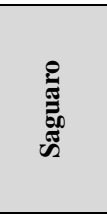 & 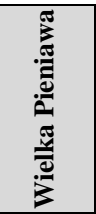 & 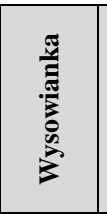 & $\begin{array}{l}\bar{\Xi} \\
\text { हूँ }\end{array}$ \\
\hline $\mathrm{Al}$ & 413,22 & - & - & - & - & - & - & 1587,58 & - & - & 10668 \\
\hline As & . & - & - & - & - & 0,7 & - & - & 1,28 & - & - \\
\hline $\mathrm{Ba}$ & 20,27 & 19,16 & 1062,28 & 16,95 & 39,61 & 11,25 & 48347,29 & 436,57 & 0 & \begin{tabular}{|l|}
427,63 \\
\end{tabular} & 1507,87 \\
\hline $\mathrm{Br}$ & 38,3 & 86,94 & 45,04 & 14,62 & 23,46 & 389,88 & 29,07 & 1159,11 & 21,586 & $1526,22 \mid$ & 4944 \\
\hline Co & - & - & - & - & - & - & - & - & 2,59 & - & - \\
\hline $\mathrm{Cr}$ & 1,86 & 4,77 & - & 0,62 & 3,33 & 8,31 & 10,19 & - & - & - & - \\
\hline $\mathrm{Cu}$ & 1,06 & 2,77 & 1,37 & 0,46 & 3,35 & 0,78 & 6,07 & - & 1,2 & 4,92 & 0 \\
\hline $\mathrm{Fe}$ & 23,38 & 53,84 & 18,01 & 52,42 & 26,38 & 15,71 & 92,71 & 49,91 & 28,19 & 32,36 & 472,57 \\
\hline $\mathrm{Ge}$ & - & - & - & - & - & - & - & 6,49 & - & 7,04 & - \\
\hline $\mathrm{I}$ & - & - & - & - & - & - & - & - & - & - & - \\
\hline $\mathrm{Mn}$ & - & - & 169,91 & 0,65 & - & - & 296,11 & 44,66 & 255,49 & 243,65 & - \\
\hline $\mathrm{Ni}$ & - & - & - & - & - & - & - & - & - & - & - \\
\hline $\mathrm{P}$ & - & 956,47 & - & - & - & - & - & - & - & - & - \\
\hline $\mathrm{Rb}$ & \begin{tabular}{|l|}
4,4326 \\
\end{tabular} & - & 19,0237 & 3,1417 & 3,4605 & - & 21,92 & 50,89 & 175,43 & \begin{tabular}{|l|l|}
75,777 \\
\end{tabular} & 441,53 \\
\hline $\mathrm{Se}$ & - & 0,56 & - & - & - & - & - & - & - & - & - \\
\hline $\mathrm{Sr}$ & 2294,5 & 567,31 & 803,46 & 302,73 & 437,57 & 2523,74 & 16619,86 & 468,35 & 509,19 & 459,72 & 1649,59 \\
\hline $\mathrm{Ti}$ & - & 12,66 & - & - & 5,53 & - & - & - & - & - & - \\
\hline $\mathrm{Zn}$ & 3,89 & 6,98 & 10,04 & 2,94 & 14,71 & 6,22 & 22,61 & 8,16 & 6,88 & 11,35 & 47,85 \\
\hline
\end{tabular}

\subsection{Częstość występowania}

Badane wody nie wykazują dużej zmienności pod względem zawartości mikroskładników. Tabela 3 przedstawia częstość występowania poszczególnych mikroskładników w badanych wodach.

Mikroskładniki, które obecne były we wszystkich 22 przebadanych wodach to stront, cynk i żelazo. Bar nie występował tylko w Wielkiej Pieniawie, a brom w Celestynce. Pierwiastki, które wykrywane były najrzadziej to tytan, selen, nikiel, jod i kobalt.

\subsection{Najwyższe stężenia}

W tabeli 4 przedstawiono wody, w których odnotowano najwyższe stężenia mikroskładników. Badania wykazały, że najwyższe stężenia mikroskładników w przeważającej większości występują w wodach leczniczych. Nisko zmineralizowana woda Dobrowianka jest najbogatsza pod względem zawartości arsenu i cynku. Tytan i selen w najwyższym stężeniu występują w wodzie Perrier. 
Tabela 3. Częstość występowania mikroskładników w badanych wodach [\%]

Table 3. Incidence of microelements in waters used in study [\%]

\begin{tabular}{|c|c|}
\hline Pierwiastek & Częstość występowania [\%] \\
\hline $\mathrm{Zn}$ & 100 \\
\hline $\mathrm{Sr}$ & 100 \\
\hline $\mathrm{Fe}$ & 100 \\
\hline $\mathrm{Br}$ & 95 \\
\hline $\mathrm{Ba}$ & 95 \\
\hline $\mathrm{Rb}$ & 86 \\
\hline $\mathrm{Cu}$ & 77 \\
\hline $\mathrm{Mn}$ & 59 \\
\hline $\mathrm{Cr}$ & 59 \\
\hline $\mathrm{Al}$ & 36 \\
\hline $\mathrm{P}$ & 27 \\
\hline $\mathrm{Ge}$ & 23 \\
\hline $\mathrm{As}$ & 14 \\
\hline $\mathrm{Ti}$ & 9 \\
\hline $\mathrm{Se}$ & 9 \\
\hline $\mathrm{Ni}$ & 9 \\
\hline $\mathrm{I}$ & 9 \\
\hline $\mathrm{Co}$ & 9 \\
\hline
\end{tabular}

Tabela 4. Najwyższe stężenia mikroskładników $\left[\mu g \cdot d m^{-3}\right]$

Table 4. Highest concentrations of microelements $\left[\mu \mathrm{g} \cdot \mathrm{dm}^{-3}\right]$

\begin{tabular}{|c|r|c|}
\hline Pierwiastek & $\begin{array}{c}\text { Najwyższe stężenie } \\
\left.\left[\mu \mathrm{g} \cdot \mathrm{dm}^{-3}\right]\right]\end{array}$ & $\begin{array}{c}\text { Woda } \\
\text { butelkowana }\end{array}$ \\
\hline $\mathrm{Al}$ & 10668,0 & Zuber \\
\hline $\mathrm{As}$ & 1,4 & Dobrowianka \\
\hline $\mathrm{Ba}$ & 48347,3 & Słotwinka \\
\hline $\mathrm{Br}$ & 12350,8 & Franciszek \\
\hline $\mathrm{Co}$ & 7,1 & Jan \\
\hline $\mathrm{Cr}$ & 10,2 & Słotwinka \\
\hline $\mathrm{Cu}$ & 9,5 & Henryk \\
\hline $\mathrm{Fe}$ & 472,6 & Zuber \\
\hline $\mathrm{Ge}$ & 53,6 & Franciszek \\
\hline $\mathrm{I}$ & 1628,0 & Franciszek \\
\hline $\mathrm{Mn}$ & 454,3 & Jan \\
\hline $\mathrm{Ni}$ & 20,5 & Jan \\
\hline $\mathrm{P}$ & 3040,6 & Franciszek \\
\hline $\mathrm{Rb}$ & 441,5 & Zuber \\
\hline $\mathrm{Se}$ & 0,6 & Perrier \\
\hline $\mathrm{Sr}$ & 16619,9 & Słotwinka \\
\hline $\mathrm{Ti}$ & 12,7 & Perrier \\
\hline $\mathrm{Zn}$ & 74,2 & Dobrowianka \\
\hline
\end{tabular}




\subsection{Fizjologiczne znaczenie mikroskładników}

Wojtaszek [8] w opracowaniu „Profilaktyczno zdrowotne działanie wód mineralnych" podaje, że składniki mineralne występujące w wodach mogą mieć znaczenie fizjologiczne jeśli ich ilość przekracza 15\% dziennego zapotrzebowania. Obecnie nie jest określone dzienne zapotrzebowanie dla wszystkich mikroskładników. To, które dotychczas poznano przedstawione zostało w tabeli 5.

W tabeli 6 przedstawiono ilość mikroskładników mających znaczenie fizjologiczne, która jest dostarczana do organizmu wraz z wypijaną wodą. W nawiasach podano procentowe pokrycie dziennego zapotrzebowania na dany mikroelement. Założono dzienne spożycie wody w ilości $1,5 \mathrm{dm}^{3}$. Wody lecznicze nie zostały ujęte w tym zestawieniu, gdyż dawkowanie tych wód, ze względu na ich specyficzne właściwości, musi być kontrolowane przez lekarza.

Tabela 5. Dzienne zapotrzebowanie na mikroelementy, na podstawie [3]

Table 5. Recommended daily amount for microelements, based on [3]

\begin{tabular}{|c|c|c|}
\hline Składnik & $\begin{array}{c}\text { Dzienne zapotrzebowanie } \\
{\left[\boldsymbol{\mu} \boldsymbol{g} \cdot \boldsymbol{d}^{-\mathbf{1}}\right]}\end{array}$ & $\begin{array}{c}\mathbf{1 5} \% \text { dziennego zapotrzebowania } \\
{\left[\boldsymbol{\mu \boldsymbol { g }} \cdot \boldsymbol{d}^{\mathbf{- 1}}\right]}\end{array}$ \\
\hline $\mathrm{Co}$ & 0,3 & 0,045 \\
\hline $\mathrm{Cr}$ & 100 & 15 \\
\hline $\mathrm{Cu}$ & 2000 & 300 \\
\hline $\mathrm{Fe}$ & 15000 & 2250 \\
\hline $\mathrm{Mn}$ & 3000 & 450 \\
\hline $\mathrm{Ni}$ & 100 & 15 \\
\hline $\mathrm{P}$ & 3500000 & 525000 \\
\hline $\mathrm{Se}$ & 60 & 9 \\
\hline $\mathrm{Zn}$ & 13000 & 1950 \\
\hline
\end{tabular}

Wyniki pokazują, że żadna z badanych wód mogąca służyć jako stałe źródło płynów w diecie, nie zawiera mikroskładników w ilości, która pozwalałaby na fizjologiczno-odżywcze oddziaływanie na organizm. Można jednak zauważyć, że w kilku wodach zawartość chromu i manganu jest wyraźnie bliska osiągnięcia granicy fizjologiczno odżywczej. Dla chromu jest to: S. Pellegrino $(12,47 \%)$, Evian (7,88\%), Perrier (7,16\%) i Kryniczanka (5,58\%). Dla manganu: Muszynianka (14,68\%), Wysowianka (10,44\%), Piwniczanka $(7,28 \%)$ i Kryniczanka $(5,68 \%)$. 
Pierwiastki śladowe w wybranych wodach mineralnych...

Tabela 6. Ilość mikroskładników dostarczana wraz z wypijaną woda przy założeniu spożycia $1,5 \mathrm{dm}^{3}$ wody dziennie $[\mu \mathrm{g}]$ oraz pokrycie dziennego zapotrzebowania na dany pierwiastek [\%]

Table 6. Amount of microelements supplied with water $\left(1,5 \mathrm{dm}^{3}\right.$ per day) $[\mu \mathrm{g}]$ and covering recommended daily amount for each element [\%]

\begin{tabular}{|c|c|c|c|c|c|c|c|c|}
\hline & \multicolumn{8}{|c|}{ Woda butelkowana } \\
\hline $\begin{array}{l}\text { Pierwia- } \\
\text { stek }\end{array}$ & Celestynka & Cisowianka & \begin{tabular}{|l}
$\begin{array}{l}\text { Dobro- } \\
\text { wianka }\end{array}$ \\
\end{tabular} & Evian & Jurajska & \begin{tabular}{|c|} 
Kinga \\
Pienińska
\end{tabular} & \begin{tabular}{|} 
Kryniczan- \\
ka
\end{tabular} & $\begin{array}{l}\text { Muszy- } \\
\text { nianka }\end{array}$ \\
\hline Co & - & - & - & - & - & - & - & - \\
\hline $\mathrm{Cr}$ & - & $\begin{array}{c}2,1 \\
(2,09)\end{array}$ & - & $\begin{array}{c}\mathbf{7 , 9} \\
(\mathbf{7 , 8 8})\end{array}$ & - & $\begin{array}{c}2,4 \\
(2,42)\end{array}$ & $\begin{array}{c}5,6 \\
(5,58)\end{array}$ & - \\
\hline $\mathrm{Cu}$ & - & $\begin{array}{c}1,5 \\
(0,08)\end{array}$ & $\begin{array}{c}1,6 \\
(0,08)\end{array}$ & $\begin{array}{c}0,9 \\
(0,05)\end{array}$ & $\begin{array}{c}1,2 \\
(0,06)\end{array}$ & $\begin{array}{c}1,2 \\
(0,06)\end{array}$ & $\begin{array}{c}6,5 \\
(0,33)\end{array}$ & $\begin{array}{c}2,9 \\
(0,14)\end{array}$ \\
\hline $\mathrm{Fe}$ & $\begin{array}{c}78,1 \\
(0,52) \\
\end{array}$ & $\begin{array}{c}42,5 \\
(0,28) \\
\end{array}$ & $\begin{array}{c}19,6 \\
(0,13) \\
\end{array}$ & $\begin{array}{c}46,3 \\
(0,31) \\
\end{array}$ & $\begin{array}{c}24,8 \\
(0,17) \\
\end{array}$ & $\begin{array}{c}9,8 \\
(0,07) \\
\end{array}$ & $\begin{array}{c}55,9 \\
(0,37) \\
\end{array}$ & $\begin{array}{c}44,9 \\
(0,30) \\
\end{array}$ \\
\hline $\mathrm{Mn}$ & - & - & - & $\begin{array}{c}1,2 \\
(0,03)\end{array}$ & - & $\begin{array}{c}0,9 \\
(0,03)\end{array}$ & $\begin{array}{l}198,6 \\
(5,68)\end{array}$ & $\begin{array}{c}513,9 \\
(14,68)\end{array}$ \\
\hline $\mathrm{Ni}$ & - & - & - & - & - & - & - & - \\
\hline$P$ & - & $\begin{array}{l}1122,5 \\
(0,03)\end{array}$ & - & - & - & - & - & $\begin{array}{l}1863,3 \\
(0,05)\end{array}$ \\
\hline $\mathrm{Se}$ & - & - & - & - & - & $0,2(0,41)$ & - & - \\
\hline \multirow[t]{2}{*}{$\mathrm{Zn}$} & $\begin{array}{c}15,7 \\
(0,12)\end{array}$ & $\begin{array}{c}8,0 \\
(0,06)\end{array}$ & $\begin{array}{l}111,2 \\
(0,86)\end{array}$ & $\begin{array}{c}5,4 \\
(0,04 \\
\end{array}$ & $\begin{array}{c}7,8 \\
(0,06) \\
\end{array}$ & $\begin{array}{c}10,3 \\
(0,08)\end{array}$ & $\begin{array}{c}10,1 \\
(0,08)\end{array}$ & $\begin{array}{c}16,9 \\
(0,13)\end{array}$ \\
\hline & \multicolumn{8}{|c|}{ Woda butelkowana } \\
\hline Pierwiastek & $\begin{array}{c}\text { Nałęczo- } \\
\text { wianka }\end{array}$ & Perrier & \begin{tabular}{|c|} 
Piwniczan- \\
ka
\end{tabular} & Primavera & $\begin{array}{l}\text { Rzeszo- } \\
\text { wianka }\end{array}$ & \begin{tabular}{|c|} 
S. \\
Pellegrino
\end{tabular} & Saguaro & $\begin{array}{c}\text { Wysowian- } \\
\text { ka }\end{array}$ \\
\hline Co & - & - & - & - & - & - & - & - \\
\hline $\mathrm{Cr}$ & $\begin{array}{c}3,3 \\
(3,32) \\
\end{array}$ & $\begin{array}{c}7,2 \\
(7,16)\end{array}$ & - & $\begin{array}{c}0,9 \\
(0,93)\end{array}$ & $\begin{array}{c}5,0 \\
(5,00) \\
\end{array}$ & $\begin{array}{c}12,5 \\
(12,47)\end{array}$ & - & - \\
\hline $\mathrm{Cu}$ & $\begin{array}{c}1,6 \\
(0,08)\end{array}$ & $\begin{array}{c}4,2 \\
(0,21) \\
\end{array}$ & $\begin{array}{c}2,1 \\
(0,10)\end{array}$ & $\begin{array}{c}0,7 \\
(0,03) \\
\end{array}$ & $\begin{array}{c}5,0 \\
(0,25)\end{array}$ & $\begin{array}{c}1,2 \\
(0,06)\end{array}$ & $\begin{array}{c}3,3 \\
(0,16)\end{array}$ & $\begin{array}{c}7,4 \\
(0,37) \\
\end{array}$ \\
\hline $\mathrm{Fe}$ & $\begin{array}{c}35,1 \\
(0,23) \\
\end{array}$ & $\begin{array}{c}80,8 \\
(0,54) \\
\end{array}$ & $\begin{array}{c}27,0 \\
(0,18) \\
\end{array}$ & $\begin{array}{c}78,6 \\
(0,52) \\
\end{array}$ & $\begin{array}{c}39,6 \\
(0,26) \\
\end{array}$ & $\begin{array}{c}23,6 \\
(0,16) \\
\end{array}$ & $\begin{array}{c}74,9 \\
(0,50) \\
\end{array}$ & $\begin{array}{c}48,5 \\
(0,32) \\
\end{array}$ \\
\hline $\mathrm{Mn}$ & - & - & $\begin{array}{l}254,9 \\
(7,28) \\
\end{array}$ & $\begin{array}{c}1,0 \\
(0,03) \\
\end{array}$ & - & - & $\begin{array}{c}67,0 \\
(1,91) \\
\end{array}$ & $\begin{array}{c}365,5 \\
(10,44)\end{array}$ \\
\hline $\mathrm{Ni}$ & - & - & - & - & - & - & - & - \\
\hline$P$ & - & $\begin{array}{l}1434,7 \\
(0,04)\end{array}$ & - & - & - & - & - & - \\
\hline $\mathrm{Se}$ & - & $\begin{array}{c}0,8 \\
(1,40)\end{array}$ & - & - & - & - & - & - \\
\hline $\mathrm{Zn}$ & $\begin{array}{c}5,8 \\
(0,04)\end{array}$ & $\begin{array}{c}10,5 \\
(0,08)\end{array}$ & $\begin{array}{c}15,1 \\
(0,12)\end{array}$ & $\begin{array}{c}4,4 \\
(0,03)\end{array}$ & $\begin{array}{c}22,1 \\
(0,17)\end{array}$ & $\begin{array}{c}9,3 \\
(0,07)\end{array}$ & $\begin{array}{c}12,2 \\
(0,09)\end{array}$ & $\begin{array}{c}17,0 \\
(0,13)\end{array}$ \\
\hline
\end{tabular}




\subsection{Występowanie germanu}

Badania własne wykazały obecność germanu w 5 badanych wodach: Celestynka $(1,03 \mu g / l)$, Saguaro $(6,49 \mu g / l)$, Wysowianka $(7,04 \mu g / l)$, Henryk $(17,69 \mu \mathrm{g} / \mathrm{l})$ i Franciszek $(53,59 \mu \mathrm{g} / \mathrm{l})$. Istnieje zależność między zawartością germanu i bromu w badanych wodach (Rys. 1).

Z krzywej korelacji stężenia germanu i bromu wyznaczono współczynnik dopasowania $R^{2}=0,993$. Na jego podstawie można stwierdzić że powyższe wskaźniki wykazują silną korelację dodatnią tzn. wraz ze wzrostem stężenia bromu rośnie wartość stężenia germanu.

W literaturze brak jest dokładnych danych na temat występowania germanu w polskich wodach mineralnych. Zatem uzyskane wyniki stanowią podstawę do dalszych badań.

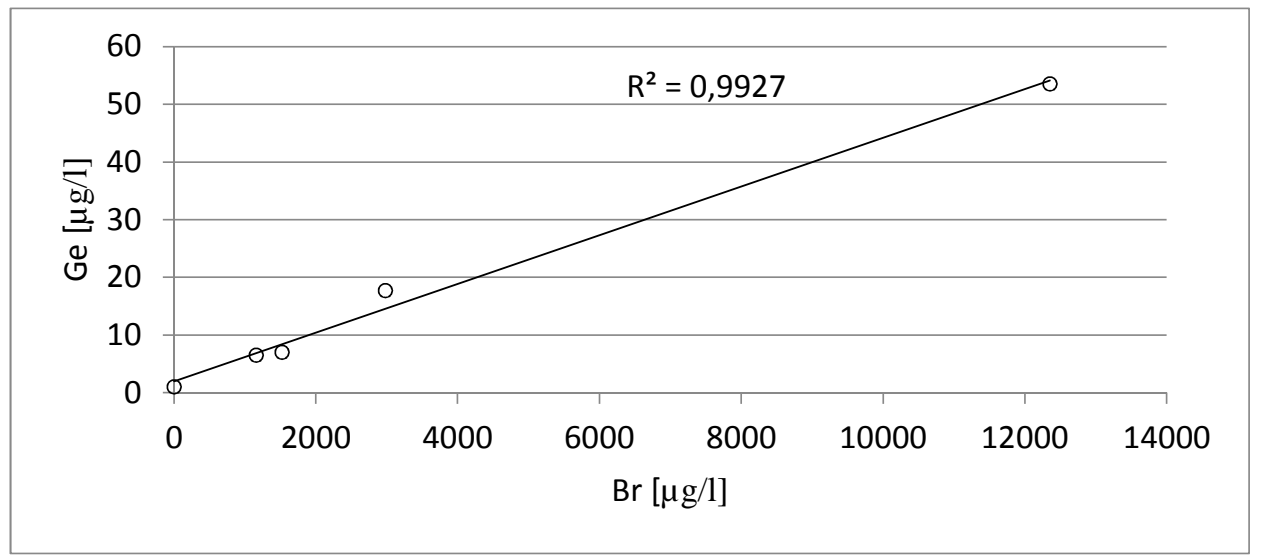

Rys. 1. Krzywa korelacji stężenia bromu i germanu

Fig. 1. Correlation graph of bromide and germanium concentration

\section{Wnioski}

$\mathrm{Na}$ podstawie przeprowadzonych analiza można wysunąc następujące wnioski i stwierdzenia:

- Mikroskładniki występujące w analizowanych 22butelkowanych wodach mineralnych to: glin, arsen, bar, brom, kobalt, chrom, miedź, żelazo, german, jod, mangan, nikiel, fosfor, rubid, selen, stront, tytan i cynk.

- Najwyższe stężenia mikroskładników w przeważającej większości występują w wodach leczniczych.

- Mikroskładniki występujące w badanych butelkowanych wodach mineralnych, z wyłączeniem wód leczniczych, nie mają znaczenia fizjologicznego. 
- German występuje w polskich butelkowanych wodach mineralnych. Pomiędzy stężeniem bromu i germanu istnieje silna korelacja dodatnia.

W badaniach wykorzystano aparaturę zakupionq w ramach projektu nr POPW.01.03.00-18-012/09

z Funduszy Strukturalnych w ramach Programu Operacyjnego Rozwój Polski Wschodniej współfinansowanego przez Unię Europejskq ze środków Europejskiego Funduszu Rozwoju Regionalnego.

\section{Literatura}

[1] Bruker AXS Microanalysis GmbH, S2 PICOFOX User Manual, 2008.

[2] Derkowska- Sitarz M., Adamczyk-Lorenc A., Wptyw składników mineralnych rozpuszczonych $w$ wodzie pitnej na organizm człowieka, Prace Naukowe Instytutu Górnictwa Politechniki Wrocławskiej. Studia i Materiały, Rocznik 2008, Tom 123, Nr 34, Str. 39-48.

[3] Gawęcki J., Hryniewiecki L.: Żywienie człowieka. Podstawy nauki o żywieniu. Wydawnictwo naukowe PWN, Warszawa 2007.

[4] Janiec B., Woda w środowisku przyrodniczym i jej kwalifikacje: Aqua minerale: dlaczego ja pijemy?, „Aura”, 2005, Nr 5, s. 4-7.

[5] Macioszczyk A., Dobrzyński D.: Hydrogeochemia. Strefy aktywnej wymiany wód podziemnych. Wydawnictwo Naukowe PWN, Warszawa 2002.

[6] Rak J.R., Pietrucha-Urbanik K., Boryczko K.: Balneotechnika. Wody mineralne. Oficyna Wydawnicza Politechniki Rzeszowskiej, Rzeszów 2013.

[7] Rak J. R., Tchórzewska-Cieślak B., Pietrucha K.: Balneotechnika. Walory uzdrowiskowe., Oficyna Wydawnicza Politechniki Rzeszowskiej, Rzeszów 2010.

[8] Wojtaszek T., Profilaktyczno-zdrowotne dziatanie wód mineralnych. Journal of Elementology, 2006, Nr 11 (1), Str. 119-126.

[9] www.bruker.poznan.pl [dostęp: 03.01.2015 r.]

\section{TRACE ELEMENTS IN SELECTED MINERAL WATERS COMMERCIALLY AVAILABLE}

\section{S u m m a r y}

Bottled mineral waters areimportant source of recommended daily amount for water. Due to the facility in assimilation elements in water by human organism, it is essential to choice consciously product with individual composition. Amount of the main elements in mineral water are always visible on the label, but there are also trace amounts of microelements. The purpose of this study was to investigate the trace elements in 22 mineral waters commercially available in Rzeszow. The paper presents the main issues of water influence on functioning of the human body and microelements influence on human health. The method which was applied in study is total reflection X-Ray Fluorencences TXRF. The results of the study were that there is 18 microelements in bottled water: : Al, As, Ba, Br, Co, Cr, Cu, Fe, Ge, I, Mn, Ni, P, Rb, Se, Sr, Ti, Zn. Zinic, strontium and iron occurred in all waters used in study. In the therapeutic water the contest of 14 microelements were the highest. Lowly-mineralized, medium-mineralized and highly-mineralized waters do not containmicroelements inan amountwhich would allow forthe physiological andnutri- 
tionaleffects on theorganism. Additionally it has been proved that there is a strong positive correlation between the concentration of bromine and germanium $\left(R^{2}=0,993\right)$.

Keywords: microelements, mineral water, bottled water, germanium

DOI:10.7862/rb.2016.286

Przestano do redakcji: 10.07.2016 $r$.

Przyjęto do druku: 20.12.2016 r. 